\title{
ANTICARIOGENIC POTENCIAL OF ACIDULATE SOLUTIONS WITH LOW FLUORIDE CONCENTRATION
}

\author{
POTENCIAL ANTICARIOGÊNICO DE SOLUÇÕES ACIDULADAS COM BAIXA \\ CONCENTRAÇÃO DE FLÚOR
}

Alberto Carlos Botazzo DELBEM${ }^{1}$, Gilberto Carlos TIANO ${ }^{2}$, Karina Mirela Ribeiro Pinto ALVES ${ }^{3}$, Robson Frederico CUNHA ${ }^{1}$

\author{
1- DDS, MS, PhD, Associate Professor, UNESP - São Paulo State University, School of Dentistry of Araçatuba - Department of Pediatric \\ Dentistry, SP, Brazil. \\ 2- Undergraduate Student, UNESP - São Paulo State University, School of Dentistry of Araçatuba - Department of Pediatric Dentistry, SP, \\ Brazil. \\ 3- DDS, MS Student, UNESP - São Paulo State University, School of Dentistry of Araçatuba - Department of Pediatric Dentistry, SP, Brazil. \\ Corresponding address: Alberto Carlos Botazzo Delbem - R. José Bonifácio, 1193, Araçatuba, SP - Cep.: 16015-050, Brazil \\ Phone:55-18-3636-3235 - Fax:55-18-3636 3332 - e-mail: adelbem@foa.unesp.br \\ Received: March 28, 2005 - Modification: November 17, 2005 - Accepted: June 12, 2006
}

\begin{abstract}
$O$

bjetives: The aim of this study was to verify the anticariogenic effect of acidulate solutions with low NaF concentration, using pH-cycling model and bovine enamel. Material and methods: Enamel blocks were submitted to the surface microhardness (SMH) test and randomly divided in 12 experimental and one placebo groups. The blocks were submitted to $\mathrm{pH}$ cycling for 7 days, with daily applications once/day of $0.05 \% \mathrm{NaF}$ and $0.1 \% \mathrm{NaF}$ and twice/day of $0.02 \% \mathrm{NaF}$ solutions. Four different $\mathrm{pH}$ : 4.0, 5.0, 6.0 and 7.0 were used. Next, SMH test was again used to determine the surface microhardness percentage change (\%SMH). Data obtained for \%SMH were homogeneous and passed through variance analyses and Tukey's test (5\%) as far as fluoride concentrations and $\mathrm{pH}$. Results:The results showed that $\mathrm{pH}$ influenced \% $\mathrm{SMH}$ in $0.02 \% \mathrm{NaF}$ and $0.05 \% \mathrm{NaF}$ solutions with $\mathrm{pH} 4.0$, which had less mineral loss compared to $\mathrm{pH} 7.0(\mathrm{p}<0.05)$. The $0.02 \% \mathrm{NaF}-\mathrm{pH} 4.0$, and $0.05 \% \mathrm{NaF}-\mathrm{pH} 7.0$ groups showed similar results ( $\mathrm{p}>0.05)$. A dose-response relationship was observed among the tested solutions, with better anticariogenic effect for the $0.1 \% \mathrm{NaF}$ solution. Conclusion: The results suggest that the addition of citric acid to acidulate mouth rinses reduce mineral loss.
\end{abstract}

Uniterms: Dental enamel, hardness; Sodium fluoride, administration \& dosage; Dental caries, prevention \& control.

\section{RESUMO}

$O$

bjetivo: O objetivo do presente estudo foi verificar o efeito anticariogênico de soluções aciduladas com baixa concentração de flúor, usando um modelo de ciclagem de $\mathrm{pH}$ e esmalte bovino. Material e Método: Blocos de esmalte foram polidos, submetidos ao teste de microdureza de superfície (SMH) e divididos aleatoriamente em 12 grupos experimentais e um placebo. Os blocos foram submetidos à ciclagem de pH por 7 dias e a aplicações diárias de soluções de $\mathrm{NaF}$ a $0,05 \%$ e $0,1 \%$ (1x) e de 0,02\% (2x), com pHs 4.0, 5.0, 6.0 e 7.0. A seguir, determinou-se a SMH novamente para o cálculo da porcentagem de alteração da microdureza de superfície (\%SMH). Os dados de \%SMH foram homogêneos e submetidos a análise de variância e teste de Tukey (5\%) considerando as concentrações de flúor e pH. Resultados: O pH influenciou a \%SMH nas soluções de NaF 0,02\% e $0,05 \%$ com $\mathrm{pH} 4.0$, no qual a perda mineral foi menor quando comparado ao $\mathrm{pH} 7.0(\mathrm{p}<0,05)$. Os grupos das soluções de $\mathrm{NaF}$ $0,02 \%$ - $\mathrm{pH} 4.0$, e de $\mathrm{NaF} 0,05 \%$ - $\mathrm{pH} 7.0$ mostraram resultados similares ( $>>0,05)$. A relação dose-resposta foi observada entre as soluções testadas, com melhor efeito anticariogênico para a solução de NaF $0,1 \%$. Conclusão: Os resultados sugerem que a acidificação das soluções com baixa concentração de fluoreto reduz a perda mineral.

Unitermos: Esmalte dentário, dureza; Fluoreto de sódio, administração \& dosagem; Cárie dentária, prevenção \& controle. 


\section{INTRODUCTION}

Fluoride use is quite relevant, mainly because it increases the saliva ability of mineral replacement of teeth during the post-eruptive phase in 2 to 4 times ${ }^{8}$. Topical fluorides are known as efficient agents for dental caries prevention ${ }^{3,14}$ and many in vitro and in vivo researches were accomplished to define their efficacy. The use of fluoride has been recommended in constant frequency and low levels for better effect $^{2}$. Studies show that the use of low-fluoride solutions can reduce enamel demineralization and increase remineralization ${ }^{1,15}$.

Different concentrations of fluoride solutions and dentifrices have been studied because of the high index of dental fluorosis. According to the literature, the fluoride amount regarded as safe ranges from 0.05 to $0.07 \mathrm{mg} \mathrm{F} / \mathrm{Kg}$ weight $/$ day $^{5}$. Some studies indicate that young children ingest a large amount of toothpaste during brushing ${ }^{17,18}$. Toddlers tend to swallow one third or more of the amount of dentifrice placed on toothbrushes ${ }^{16}$. Oral health promotion programs for toddlers (Baby Clinics) have been using topical solutions with low fluoride concentrations in the dental office $(0.2 \% \mathrm{NaF} /$ bi-monthly) and at home $(0.02 \% \mathrm{NaF} /$ day $)$ instead of fluoride dentifrice as a safety measure ${ }^{10,19,21}$. The use of $0.02 \% \mathrm{NaF}$ solutions does not lead to risk of chronic intoxication in children, even if combined with other fluoride sources to which these patients may be exposed ${ }^{13}$. However, the use of $0.02 \% \mathrm{NaF}$ solution is not based on clinical researches ${ }^{9}$. Besides that, an in vitro study did not confirm the anticariogenic effect of this concentration ${ }^{7}$. Solutions with other fluoride concentrations have been suggested, but without scientific confirmation. Thus, is very important to establish a dose-response relationship before indicating fluoride products.

According to Bijella, et al. ${ }^{4}(1994)$, the reduction of $\mathrm{pH}$ of fluoride solutions increases the anti-metabolic effect of fluoride in dental plaque. Delbem and Cury ${ }^{11}(2002)$ observed that acidulated products promoted better fluoride uptake and were more efficient to reduce mineral loss when compared to neutral products. Thus, to compensate the low reactivity, a more frequent use of neutral products has been suggested.

Therefore, it would be important to verify if $\mathrm{pH}$ alterations would improve the anticariogenic effect of low-fluoride solutions for utilization by 0 to 3 year-old children, for achievement of the dose-response risk relationship. The aim of this study was to verify the anticariogenic effect of $0.02 \%, 0.05 \%$ and $0.1 \% \mathrm{NaF}$ solutions and the influence of $\mathrm{pH}$ of these solutions, ( $\mathrm{pH} 4.0,5.0,6.0$ and 7.0), using a pHcycling model and bovine teeth.

\section{MATERIALAND METHODS}

\section{Experimental design}

One hundred and thirty enamel blocks ( $4 \times 4 \mathrm{~mm})$ achieved from bovine incisors had their enamel surfaces sequentially polished, allowing selection of blocks by determination of the initial surface microhardness (SMH). The study design was random, and the blocks were divided into 13 groups with 10 specimens each: placebo solution (deionized water), 0.02\%, 0.05\% and $0.1 \% \mathrm{NaF}$ solutions. All fluoride solutions were prepared in four different $\mathrm{pH}$ (4.0, 5.0, 6.0 and 7.0) using citric acid. The enamel blocks were submitted to a pH cycling model for analysis of the dose-response effect of fluoridated solutions. The placebo and $0.02 \% \mathrm{NaF}$ solutions were applied twice a day; $0.05 \%$ and $0.1 \%$ NaF solutions were applied once a day. After this, the blocks were submitted to a final surface microhardness analysis.

\section{Analysis of the fluoride concentration in solutions}

After the codification of the products, $1 \mathrm{~mL}$ of each solution $(0.02 \%, 0.05 \%$ and $0.1 \% \mathrm{NaF}$ solutions in $\mathrm{pH} 4.0$, 5.0, 6.0 and 7.0) was pippeted in $100 \mathrm{~mL}$ polypropylene volumetric balloons and the volume was completed with deionized water. This step was repeated 3 times. Then, three samples of $1 \mathrm{~mL}$ of each diluted solution were pippeted in polystyrene vials ( $\mathrm{J} 10$ ), with a total of nine samples of each product. Fluoride measurements were performed using an ion-selective electrode BN 9609 (Orion Research) and an ion analyzer 290A (Orion Research). Previously, a calibration curve was made with fluoride standard solutions prepared in different concentrations: 0.125 to $2.0 \mu \mathrm{g} \mathrm{F} / \mathrm{mL}$ for the $0.02 \%$ NaF solution; 0.25 to $4.0 \mu \mathrm{g} F / \mathrm{mL}$ for the $0.05 \% \mathrm{NaF}$ solution and 0.5 to $8.0 \mu \mathrm{g} \mathrm{F} / \mathrm{mL}$ for the $0.1 \% \mathrm{NaF}$ solution. Fluoride was measure after mixing $1 \mathrm{~mL}$ of the diluted sample and 1 $\mathrm{mL}$ of TISAB II, in constant and light agitation ${ }^{12,14}$.

\section{Demineralizing and remineralizing cycling}

The blocks were submitted during 7 days at $37^{\circ} \mathrm{C}$ to a pH-cycling model, according to Vieira, et al. ${ }^{20}$ (2005), altering demineralizing sessions $\left(2.0 \mathrm{mmol} \mathrm{L}^{-1}\right.$ calcium and phosphate in $75 \mathrm{mmol} \mathrm{L}^{-1}$ acetate buffer, $\mathrm{pH} 4.7 ; 0.04 \mu \mathrm{g} \mathrm{F} / \mathrm{mL}, 2.2 \mathrm{~mL} /$ $\left.\mathrm{mm}^{2}\right)$ for $6 \mathrm{~h}$, and remineralizing $\left(1.5 \mathrm{mmol} \mathrm{L}^{-1}\right.$ calcium, 0.9 mmol L-1 phosphate, $150 \mathrm{mmol} \mathrm{L}^{-1} \mathrm{KCl}$ in $0.02 \mathrm{~mol} \mathrm{~L}^{-1}$ cacodylic buffer, $\mathrm{pH} 7.0 ; 0.05 \mu \mathrm{g} \mathrm{F} / \mathrm{mL}, 1.1 \mathrm{~mL} / \mathrm{mm}^{2}$ ) for $18 \mathrm{~h}$.

The treatment regimen consisted of 30 seconds soak in $2 \mathrm{~mL} /$ block of placebo and $0.02 \%$ solutions under agitation on a rotatory shaker, before the solution changes from DE to RE and from RE to DE (twice a day). For the $0.05 \%$ and $0.1 \%$ solutions, the treatments were realized before the solution changes from RE to DE (once a day). Deionized water rinses were done between every step. In the last two days the blocks were kept in remineralizing solution.

\section{Microhardness Analysis}

Enamel microhardness measurements were realized as described by Delbem and Cury ${ }^{11}$ (2002) and performed before $(\mathrm{SMH})$ and after $\left(\mathrm{SMH}_{1}\right) \mathrm{pH}$-cycling. A Shimadzu HMV-2000 microhardness tester (Shimadzu Corporation, Kyoto, Japan) Knoop diamond under a $50 \mathrm{~g}$ load for 10 seconds coupled to a CAMS-WIN software (New Age Industries, USA) was used. The percentage change of surface microhardness $(\% \mathrm{SMH})$ was calculated $[\% \mathrm{SMH}=$ $\left.\left(\left(\mathrm{SMH}_{1}-\mathrm{SMH}\right) / \mathrm{SMH}\right) \mathrm{x} 100\right]^{20}$. 


\section{STATISTICALANALYSIS}

Since the \% SMH values were homogeneous, data obtained were submitted to the variance analyses and Tukey's test (5\%) considering fluoride concentrations and $\mathrm{pH}$, using the GMC Statistical Software ${ }^{6}$. Mean, percentage of the variation coefficient and confidence interval (95\%) were determined for fluoride values (ppm) in the solutions.

\section{RESULTS}

\section{Analysis of fluoride concentration in solutions}

Table 1 shows the fluoride content of the solutions according to the different concentrations and $\mathrm{pH}$ used in this study. All fluoride products presented means of total fluoride content within the confidence interval of 95\%. The variation coefficient obtained, referring to the concentration defined for each solution, was under $10 \%$ in all solutions.

\section{Microhardness Analysis}

Table 2 shows the \%SMH according to $\mathrm{pH}(4.0,5.0,6.0$ and 7.0 ) and $\mathrm{NaF}$ concentrations (0.02\%, $0.05 \%$ and $0.1 \%)$. Less mineral loss was observed in the $0.02 \% \mathrm{NaF}$ solution of $\mathrm{pH} 4.0$, compared to other solutions with same concentration and different $\mathrm{pH}$. Similar data were presented by $0.05 \% \mathrm{NaF}$ solutions. There was no difference related to $\mathrm{pH}$ alteration $(\mathrm{p}>0.05)$ of the $0.1 \% \mathrm{NaF}$ solution. Analyzing the effect of the fluoride concentration in solutions, less mineral loss was observed in the $0.1 \% \mathrm{NaF}$ solution $(\mathrm{p}<0.05)$. A negative correlation was found among the different fluoride concentrations and \%SMH ( $\mathrm{r}=-0.98$; $\mathrm{p}=0.021)$.

\section{DISCUSSION}

In vitro studies using $\mathrm{pH}$ cycling model should allow verification of dose-response relationship of fluoridated products. Therefore, to validate the results of the present research, the model must provide this verification ${ }^{3,20}$. The present results showed that the model employed to simulate the in vivo cariogenic challenge allowed observation of the dose-response relationship related to \%SMH and fluoride concentration of the solutions. This validates the obtained results related to the effect of acidification of fluoride solutions.

Fluoride solutions were dosed before $\mathrm{pH}$-cycling and presented means of total fluoride concentration within the 95\% confidence interval. The variation coefficient, having the defined concentration of each solution as reference (Table 1 ), was lower than $10 \%$. This variation is allowed by the Agência Nacional de Vigilância Sanitária (National Sanitary Surveillance Agency) - ANVISA ${ }^{1}$ and is similar to fluoridated mouthrinses commercially available in Brazil, according to Delbem, et al. ${ }^{14}$ (2003).

Surface microhardness analysis (SMH) is a sensitive and reproducible method to verify the initial phase of the caries

TABLE 2- $\%$ SMH values according to the fluoride concentrations and $\mathrm{pH}$ of the solutions (mean $\pm \mathrm{sd}$; $\mathrm{n}=10$ )

\begin{tabular}{lccc}
\hline pH & \multicolumn{3}{c}{ Fluoride concentrations (\% NaF) } \\
& $\mathbf{0 . 0 2}$ & $\mathbf{0 . 0 5}$ & $\mathbf{0 . 1}$ \\
\hline & & $41.9 \pm 8.5^{\mathrm{c}, \mathrm{d}}$ & $38.9 \pm 2.6^{\mathrm{d}}$ \\
5.0 & $48.3 \pm 4.4^{\mathrm{a}}$ & $49.0 \pm 2.8^{\mathrm{a}}$ & $37.4 \pm 11.1^{\mathrm{c}, \mathrm{d}}$ \\
6.0 & $53.6 \pm 3.7^{\mathrm{b}}$ & $49.1 \pm 7.0^{\mathrm{a}, \mathrm{b}}$ & $41.8 \pm 3.0^{\mathrm{c}, \mathrm{d}}$ \\
7.0 & $54.1 \pm 4.0^{\mathrm{b}}$ & $48.6 \pm 6.3^{\mathrm{a}}$ & $44.7 \pm 1.8^{\mathrm{a}, \mathrm{c}}$ \\
Placebo & $58.5 \pm 6.3^{\mathrm{b}}$ & $81.0 \pm 3.3^{\star}$ & \\
$\%$ \%MH & $53.6 \pm 5.8^{\mathrm{A}}$ & $47.3 \pm 7.0^{\mathrm{B}}$ & $40.7 \pm 6.4^{\mathrm{c}}$ \\
\hline
\end{tabular}

Means followed by distinct letters are statistically different $(p<0.05)$. Mean followed by asterisk is statistically different to others groups $(p<0.05)$. Capital letters show difference related to the effect of the concentration of fluoride.

TABLE 1- Means $(\mathrm{n}=18)$ of fluoride content $(\mathrm{ppm})$ of the experimental fluoride solutions according to their concentration and $\mathrm{pH}$

\begin{tabular}{|c|c|c|c|}
\hline \multirow[t]{2}{*}{$\mathrm{pH}$} & \multicolumn{3}{|c|}{ Fluoride concentration (\%NaF - ppm F) } \\
\hline & $0.02-90$ & $0.05-225$ & $0.1-450$ \\
\hline \multirow[t]{2}{*}{4.0} & $89.6(-0.4)^{\star}$ & $218.6(-2.8)$ & $450.9(2.2)$ \\
\hline & $(88.6 \text { to } 90.5)^{\star *}$ & (216.2 to 221.1 ) & (457.1 to 462.1 ) \\
\hline \multirow[t]{2}{*}{5.0} & $91.9(2.1)$ & $225.6(0.3)$ & $458.0(1.8)$ \\
\hline & (91.3 to 92.6$)$ & (223.8 to 227.4$)$ & (455.8 to 460.3 ) \\
\hline \multirow[t]{2}{*}{6.0} & $83.9(-6.7)$ & $225.8(0.4)$ & $439.0(-2.4)$ \\
\hline & (83.6 to 84.3$)$ & (224.8 to 226.8 ) & (437.1 to 440.8 ) \\
\hline \multirow[t]{2}{*}{7.0} & $96.2(6.8)$ & $224.3(-0.3)$ & $426.1(-5.3)$ \\
\hline & (95.8 to 96.6$)$ & (223.8 to 224.9$)$ & (424.7 to 427.4 ) \\
\hline
\end{tabular}

* percentage of the variation coefficient ; ** confidence interval (95\%). 
process $^{3}$. Also, White ${ }^{22}$ (1987) found a strong correlation $\left(\mathrm{r}^{2}=0.94 ; \mathrm{p}<0.01\right)$ using SMH or microradiographs to investigate the remineralization of incipient carious lesions. As observed above, the effect of different concentration and $\mathrm{pH}$ of solutions was verified on the enamel surface, proving the sensitivity of the method and that interactions occurred among the enamel and solutions on the enamel surface.

SMH values showed that acidification of the solutions promoted a better fulfillment for $0.02 \%$ and $0.05 \% \mathrm{NaF}$ solutions at pH 4.0 (Table 2). Acidification of the $0.1 \% \mathrm{NaF}$ solution did not show significant effect when compared to other concentrations (Table 2). Reduction in enamel mineral loss was possible only at a very acidic $\mathrm{pH}$, under the critical $\mathrm{pH}$ of enamel (5.5). However, citric acid, which is a weak acid, was used as acidulating agent, because it is comestible, so that it can be ingested without health damage, an important attribute when consumed by babies. Therefore, it promotes less enamel demineralization and ion release (calcium and phosphate) in order to allow reaction with the fluoride of the solutions. This reaction is important for formation of calcium fluoride, which is responsible for the anticariogenic effect of topical products ${ }^{11}$.

An important finding was that, at $\mathrm{pH} 4.0$, the $0.02 \% \mathrm{NaF}$ promoted similar results when compared to the $0.05 \%$ solution at $\mathrm{pH} 7.0,6.0$ and 5.0. Thus, the use of this experimental solution in babies can be effective for daily use with a lower risk of development of dental fluorosis. This is due to the amount of fluoride applied, and the quantity that could be ingested from the use of the $0.02 \% \mathrm{NaF}$ solution twice a day would be lower compared to utilization of the $0.05 \% \mathrm{NaF}$ solution only once a day, what reinforces the possibility of its use. However, this study did not evaluate the influence from saliva as a buffering element capable of excluding the effect observed in the in vitro study. Therefore, it would be important to test the formulations able to keep this effect without being inactivated by the buffering capacity of saliva.

The results of the present study suggest a doseresponse relationship among the experimental solutions tested, with better anticariogenic effect for the $0.1 \% \mathrm{NaF}$ solution. Acidification of the experimental solutions promoted better anticariogenic effect only at $\mathrm{pH} 4.0$, for the $0.02 \%$ and $0.05 \% \mathrm{NaF}$ solutions.

\section{ACKNOWLEDGEMENTS}

The authors thank Natura Cosméticos S/A for manufacture the fluoride solutions. This study was supported by PIBIC/ CNPq.

\section{REFERENCES}

1- Agência Nacional de Vigilância Sanitária (ANVISA). Resolução RDC n. 79, ago 2000.

2- Arends J, Gelhard T. In vivo remineralization of human enamel. In: Leach SA, Edgar WM, editors. Demineralization and remineralization of the teeth. Oxford: IRL Press; 1983. p. 1-16.

3- Argenta RMO, Tabchoury CPM, Cury JA. A modified pH-cycling model to evaluate fluoride effect on enamel demineralization. Pesqui Odontol Bras. 2003;17(3):241-6.

4- Bijella MFTB, Melo NL, Tárzia O, Bijella VT. Avaliação do efeito inibidor de bochechos diários com fluoreto de sódio neutro e acidulado a $0,05 \%$ sobre o metabolismo da placa dentária humana (fermentação e síntese de polissacarídeos extracelulares). CECADE News. 1994;2:119

5- Burt BA. The changing patterns of systemic fluoride intake. J Dent Res. 1992;71:1228-37.

6- Campos GM. GMC 2002 [computer program]. Ribeirão Preto: School of Dentistry, http://www.forp.usp.br/restauradora/gmc/ gmc.html\#gmc. Accessed on Feb 21, 2003.

7- Chedid SJ, Cury JA. Effect of $0.02 \%$ NaF solution on enamel demineralization and fluoride uptake by deciduous teeth in vitro. Pesqui Odontol Bras. 2004;18(1):18-22.

8- Cury JA. Uso do flúor e o controle da cárie como doença. In: Baratieri, LN, et al. Odontologia Restauradora: fundamentos e possibilidades. 2. ed. São Paulo: Ed. Santos; 2001. p. 34-68.

9- Cury JA, Narvai PC, Fernandez RAC, Forni TIB, Soares MC. Recomendações sobre o uso de produtos fluorados no âmbito do SUS/ SP em função do risco de cárie dentária. 2000. p.1-10. Disponível em < http://www.saude.sp.gov.br>

10- Cunha RF, Delbem ACB, Percinoto C, Saito TE. Dentistry for babies: a preventive protocol. J Dent Child. 2000;67:89-92.

11- Delbem ACB, Cury JA. Effect of application time of APF and $\mathrm{NaF}$ gels on microhardness and fluoride uptake of in vitro enamel caries. Am J Dent. 2002;15:169-72.

12- Delbem ACB, Vieira AEM, Cury JA. Avaliação do potencial cariostático do dentifrício brasileiro de maior participação no mercado. Rev Bras Odontol. 2002;59:14-8.

13- Delbem ACB, Sassaki KT, Castro AM, Pinto LMCP, Bergamaschi M. Avaliação do teor de flúor de soluções para bochechos e de géis e o risco de intoxicação aguda. Rev ABO Nac. 2003;11:188-93.

14- Delbem ACB, Sassaki KT, Castro AM, Pinto LMCP, Bergamaschi $\mathrm{M}$. Assessment of the fluoride concentration and $\mathrm{pH}$ in different mouth rinses on the brazilian market. J Appl Oral Sci. 2003;11:31923.

15- Delbem ACB, Cunha RF, Percinoto C. A importância do flúor e agentes quimioterápicos na prevenção da doença cárie em pacientes com necessidades especiais. In: Cardoso RJA, Machado MEL, editors. Odontologia, conhecimento e arte: odontopediatria, ortodondia, ortopedia funcional dos maxilares, pacientes especiais. São Paulo: Artes Médicas; 2003. v.2,p. 309-16.

16- Horowitz HS. The need for toothpastes with lower than conventional fluoride concentrations for preschool-aged children. J Public Health Dent. 1992;52(4):216-21.

17- Lima YBO, Cury, JA. Fluoride intake by children from water and dentifrice. Rev Saúde Pública. 2001;35(6):576-81. 
18- Pessan J, Silva SMB, Buzalaf MAR. Evaluation of total fluoride intake of 4-7-year-old children from diet and dentifrice. J Appl Oral Sci. 2003;11(2):150-6.

19- Vaz MA. Educar para prevenir. O trunfo da Odontopediatria. APCD. 2005;59(4):247-58.

20- Vieira AEM, Delbem ACB, Sassaki KT, Rodrigues E, Cury JA, Cunha RF. Fluoride dose response in $\mathrm{pH}$-cycling models using bovine enamel. Caries Res. 2005;39(6):514-20.

21- Walter LRF, Ferelle A, Issao M. Odontologia para o Bebê. São Paulo: Ed. Artes médicas;1996. p.246.

22- White DJ. Reactivity of fluoride dentifrices with artificial caries. Caries Res. 1987;21:126-40. 